\title{
PENGARUH STRES KERJA DAN MOTIVASI KERJA TERHADAP KINERJA PEGAWAI PADA BADAN PENGEMBANGAN SUMBER DAYA MANUSIA PROVINSI PAPUA
}

\author{
Pingkan Emmy 1 \\ pingkan_emmy@gmail.com \\ Johanis R. Wanma ${ }^{2}$ \\ johanisw@yahoo.com \\ 1-2 Fakultas Ekonomi dan Bisnis Universitas Cenderawasih,
}

\begin{abstract}
Abstraksi:
Penelitian ini bertujuan untuk mengetahui pengaruh stres kerja dan motivasi kerja secara parsial dan simultan serta mengetahui variabel manakah yang berpengaruh dominan terhadap kinerja pegawai pada BPSDM Provinsi Papua. Metode analisis yang digunakan adalah analisis regresi berganda. Analisis regresi linier berganda merupakan regresi yang memiliki satu variabel dependen dan dua atau lebih variabel independen. Hasil penelitian menunjukkan bahwa secara individu stres kerja dan motivasi kerja mampu memberikan dampak positif terhadap kinerja pegawai pada Badan Pengembangan Sumber Daya Manusia Provinsi Papua, hal ini berarti bahwa semakin rendah tingkat stres pegawai pada organisasi dan semakin baik motivasi kerja yang diberikan oleh pimpinan kepada bawahan, akan meningkatkan variabel kinerja pegawai, sebaliknya semakin tinggi tingkat stres karyawan dan semakin rendah motivasi yang diberikan oleh pimpinan/organisasi kepada pegawai, maka kinerja pegawai juga akan menurun.Secara bersama-sama stres kerja dan motivasi kerja mampu memberikan dampak positif terhadap kinerja pegawai pada Badan Pengembangan Sumber Daya Manusia Provinsi Papua. Hal ini berarti bahwa, stres kerja dan motivasi kerja dalam waktu yang sama mampu meningkatkan kinerja pegawai pada Badan Pengembangan Sumber Daya Manusia Provinsi Papua.Variabel motivasi kerja memiliki dampak yang dominan terhadap kinerja pegawai pada Badan Pengembangan Sumber Daya Manusia Provinsi Papua. Hal ini berarti bahwa, motivasi kerja memiliki dampak yang paling erat dalam meningkatkan kinerja pegawai pada Badan Pengembangan Sumber Daya Manusia Provinsi Papua.
\end{abstract}

Kata Kunci : Stres Kerja, Motivasi Kerja, Kinerja Pegawai.

\section{PENDAHULUAN}

\section{A. Latar Belakang}

Sumber Daya Manusia (SDM) memberikan pengaruh yang sangat besar, semakin baik SDM yang dimiliki oleh instansi maka akan semakin baik kinerja dari instansi itu sendiri. Manajemen sumber daya manusia sangatlah penting bagi instansi ataupun perusahaan dalam mengelola dan mengatur pegawai untuk dapat berfungsi secara produktif guna tercapainya tujuan instansi. Untuk menilai bahwa pegawai tersebut bekerja dengan maksimal atau tidak, instansi membuat suatu target pencapaian yang harus diselesaikan oleh pegawai tersebut. Inilah yang disebut dengan tuntutan kerja. Dari tuntutan kerja ini, instansi mengharapkan suatu hasil maksimal terhadap para karyawannya sehingga instansi dapat melaju dengan pesat. Namun, tidak jarang justru tuntutan kerja ini menjadikan para pegawai tegang baik fisiologis maupun psikologis. Rasa tegang inilah yang disebut dengan stres kerja.

Stres kerja pada karyawan merupakan salah satu masalah yang perlu diperhatikan dalam meningkatkan kualitas SDM yang dimiliki. Stres sebagai suatu ketidakseimbangan antara keinginan dan kemampuan memenuhinya sehingga menimbulkan konsekuensi penting bagi dirinya. Stres sebagai suatu kondisi dinamis di mana individu dihadapkan pada kesempatan, hambatan dan keinginan dan hasil yang diperoleh sangatlah penting tetapi tidak dapat dipastikan (Robbins, 2008). Dampak stres kerja menurut Luthans (2005) dibagi menjadi dua yaitu, dampak terhadap perusahaan dan dampak terhadap individu. Dampak terhadap perusahaan berupa terjadinya kekacauan dan hambatan baik dalam manajemen maupun operasional kerja. Sedangkan dampak terhadap individu berupa kesehatan, psikologis dan interaksi interpersonal.

Menurut Sinaga dan Sinambela (2013) efek psikologi yang paling sederhana dari stres kerja adalah menurunnya motivasi kerja dan kinerja pada pegawai. Motivasi kerja adalah hal yang menyebabkan, menyalurkan, dan mendukung perilaku manusia, supaya mau bekerja giat dan antusias mencapai hasil kerja yang optimal (Hasibuan, 2013). Menurut penelitian yang dilakukan oleh Dewi dan Wibawa (2016) menyatakan bahwa motivasi kerja mempunyai pengaruh positif dan 
signifikan terhadap kinerja karyawan pada PT. Bank BPD Bali Cabang Ubud artinya, semakin tinggi motivasi maka kinerjanya akan meningkat dan ketika motivasi kerja pegawai menurun maka kinerja pegawai juga akan menurun.

Mangkunegara (2009) menyatakan kinerja adalah hasil kerja baik secara kualitas dan kuantitas yang dicapai seseorang atau karyawan melalui serangkaian tindakan dan kemampuan untuk melaksanakan tugas-tugas pekerjaannya sesuai dengan tanggung jawab yang diberikan kepada karyawan oleh suatu perusahaan. Menurut Gibson, et.al, (1994) kinerja merujuk kepada tingkat keberhasilan dalam melaksanakan tugas serta kemampuan untuk mencapai tujuan yang telah ditetapkan. Individu yang memiliki kinerja yang tinggi umumnya berorientasi pada prestasi, memiliki kepercayaan diri, berpengendalian diri, dan memiliki kompetensi. Menurut Mathis dan Jackson (2001) faktor-faktor yang mempengaruhi kinerja individu, yaitu: kemampuan, motivasi, dukungan yang diterima, keberadaan pekerjaan yang dilakukan, dan hubungan dengan organisasi.

Stres kerja merupakan suatu fenomena yang bisa terjadi pada kantor manapun tidak terkecuali BPSDM Provinsi Papua. BPSDM Provinsi Papua mempunyai berbagai bidang didalamnya dan masing-masing bidang tentunya mempunyai tingkat kesulitan kerja yang berbeda-beda. Berdasarkan hasil wawancara yang dilakukan peneliti pada saat magang di BPSDM Provinsi Papua terdapat kekurangan pegawai yang membuat pekerjaan menjadi kurang efektif sehingga ini menjadi beban kerja yang dirasakan oleh pegawai BPSDM Provinsi Papua. Berkaitan dengan hal tersebut, hal ini diduga dapat mempengaruhi stres kerja pada pegawai dikarenakan tekanan kerja yang tinggi, membutuhkan kesabaran dalam melaksanakan pekerjaannya dan pencapaian target yang ditentukan dalam waktu tertentu hingga pegawai diharuskan untuk lembur, hal ini menjadi beban kerja yang dirasakan oleh pegawai BPSDM dan dapat mengakibatkan kinerja pegawai menurun. Selain stres kerja, faktor lain yang diduga mempengaruhi kinerja pegawai adalah kurangnya motivasi kerja pada pegawai. Salah satu hal yang dapat menurunkan motivasi pada pegawai BPSDM Provinsi Papua adalah fasilitas yang kurang memadai (komputer). Dengan adanya hal tersebut diperlukan pemberian motivasi pada pegawai. Pemberian motivasi menjadi landasan yang tepat dalam menimbulkan rasa disiplin terhadap pekerjaan. Salah satu motivasi yang diberikan oleh instansi berupa pemberian insentif. Pemberian instentif merupakan salah satu cara dalam meningkatkan kualitas kerja pegawai sehingga tercapai tujuan pada instansi tersebut.

Dari beberapa fenomena yang terjadi pada BPSDM Provinsi Papua, hal yang berpengaruh bagi pegawai sehingga mengalami stres kerja adalah beban kerja dalam penggunaan waktu untuk menyelesaikan pekerjaan tidak sesuai dengan beban kerja yang di berikan. Maka di perlukan motivasi kerja agar dapat meningkatkan kinerja pegawai. Berdasarkan hal-hal yang dikemukakan di atas maka penelitian ini dilakukan untuk mengetahui seberapa besar pengaruh dari stres kerja dan motivasi kerja terhadap kinerja pegawai dimana dalam hal ini diperlukan suatu kajian yang mendalam untuk mengetahuinya melalui kegiatan penelitian dengan judul "Pengaruh Stres Kerja Dan Motivasi Kerja Terhadap Kinerja Pegawai Badan Pengembangan Sumber Daya Manusia Provinsi Papua".

\section{B. Perumusan Masalah}

Berdasarkan latar belakang yang dikemukakan di atas, maka dirumuskan permasalahan penelitian sebagai berikut:

1. Apakah stress kerja dan motivasi kerja secara parsial secara parsial berpengaruh signifikan terhadap kinerja pegawai pada BPSDM Provinsi Papua?

2. Apakah stress kerja dan motivasi kerja secara simultan berpengaruh signifikan terhadap kinerja pegawai pada BPSDM Provinsi Papua?

3. Variable manakah diantara stress kerja dan motivasi kerja berpengaruh dominan terhadap kinerja pegawai pada BPSDM Provinsi Papua?

\section{Tujuan Penelitian}

Adapun tujuan penulisan yang akan dikemukakan adalah :

1. Untuk mengatahui pengaruh stress kerja dan motivasi kerja secara parsial terhadap kinerja pegawai pada BPSDM Provinsi Papua.

2. Untuk mengatui pengaruh stress kerja dan motivasi kerja secara simultan terhadap kinerja pegawai pada BPSDM Provinsi Papua.

3. Untuk mengetahui variable manakah yang berpengaruh dominan terhadap kinerja pegawai BPSDM Provinsi Papua. 


\section{LANDASAN TEORI}

\section{A. Kajian Teori}

\section{Stress Kerja}

Menurut Yusuf (2004) Istilah stres tidak dapat dipisahkan dari distress dan depresi, karena satu sama lainnya saling terkait. Stres merupakan reaksi fisik terhadap permasalahan kehidupan yang dialaminya dan apabila fungsi organ tubuh sampai terganggu dinamakan distress. Sedangkan depresi merupakan reaksi kejiwaan terhadap situasi yang penuh tekanan yang dialaminya. Menurut Romli (2010) Mengemukakan bahwa stres merupakan suatu tekanan akibat bekerja juga akan mempengaruhi emosi, proses berpikir dan kondisi fisik seseorang, dimana tekanan itu berasal dari lingkungan pekerja tempat individu tersebut berada. Menurut Mangkunegara (2008) Stres kerja adalah perasaan tertekan yang dialami karyawan dalam menghadapi pekerjaan. Stres kerja tampak dari gejala, antara lain emosi tidak stabil, perasaan tidak tenang, suka menyindir, sulit tidur, merokok yang berlebihan, tidak bisa rileks, cemas, tegang, gugup, dan tekanan darah meningkat. Berdasarkan pendapat tersebut diatas maka dapat disimpulkan bahwa stres kerja merupakan suatu proses yang dapat mempengaruhi kondisi psikologi dan mengganggu seseorang dalam pekerjaannya. jadi stres dapat dikelola atau dikurangi dengan aktif dalam kegiatan organisasi atau perusahaan.

Terdapat dua faktor penyebab atau sumber munculnya stres kerja, yaitu faktor lingkungan kerja dan faktor personal (Dwiyanti, 2001). Faktor lingkungan kerja dapat berupa kondisi fisik, manajemen kantor maupun hubungan sosial di lingkungan pekerjaan. Sedang faktor personal bisa berupa tipe kepribadian, peristiwa atau pengalaman pribadi maupun kondisi sosial ekonomi keluarga di mana pribadi berada dan mengembangkan diri. Betapapun faktor kedua tidak secara langsung berhubungan dengan kondisi pekerjaan, namun karena dampak yang ditimbulkan pekerjaan cukup besar, maka faktor pribadi ditempatkan sebagai sumber atau penyebab munculnya stres.

\section{Indikator Stress Kerja}

Indikator Stress Kerja menurut Mulyadi (2012), yaitu:

a. Kondisi pekerjaan meliputi beban kerja berlebihan, jadwal bekerja

b. Stress karena peran antaralain ketidakjelasan peran

c. Faktor interpersonal meliputi kerjasama antar teman, hubungan dengan pimpinan

d. Perkembangan karir Antara lain: promosi kejabatan yang lebih rendah dari kemampuannya, promosi kejabatan yang lebih tinggi dari kemampuannya, keamanan pekerjaannya.

\section{Motivasi Kerja}

Motivasi adalah sekelompok faktor yang menyebabkan individu berperilaku dalam cara-cara tertentu (Grifin, 2003). Motivasi merujuk pada kekuatan-kekuatan internal dan eksternal seseorang yang membangkitkan antusiasme dan perlawanan untuk melakukan serangkaian tindakan tertentu. Motivasi karyawan mempengaruhi kinerja, dan sebagian tugas seorang manajer adalah menyalurkan motivasi menuju pencapaian tujuan-tujuan organisasional. Motivasi mempersoalkan bagaimana caranya mendorong gairah kerja bawahan, agar mereka mau bekerja keras dengan memberikan semua kemampuan dan keterampilannya untuk mewujudkan tujuan perusahaan. Sedangkan motivasi tersebut adalah daya pendorong yang mengakibatkan seorang anggota organisasi mau dan rela waktunya untuk menyelenggarakan berbagai kegiatan yang menjadi tanggung jawabnya dan menunaikan kewajibannya dalam rangka pencapaian tujuan dan berbagai sasaran organisasi yang ditentukan sebelumnya (Siagian, 2003). Menurut Hasibuan (2003:95) bahwa motivasi kerja adalah pemberian daya penggerak yang menciptakan kegairahan kerja seseorang agar mereka mau bekerja sama, bekerja efektif dan terintegrasi dengan segala daya upayanya untuk mencapai kepuasan. Faktor pendorong penting yang menyebabkan manusia bekerja adalah adanya kebutuhan yang harus dipenuhi.

Dari pendapat para ahli diambil kesimpulan motivasi adalah berbagai usaha yang dilakukan oleh manusia tentunya untuk memenuhi keinginan dan kebutuhannya. Namun, agar keinginan dan kebutuhannya dapat terpenuhi tidaklah mudah didapatkan apabila tanpa usaha yang maksimal. Dalam pemenuhan kebutuhannya, seseorang akan berperilaku sesuai dengan dorongan yang dimiliki dan apa yang mendasari perilakunya. 


\section{Manfaat Motivasi Kerja}

Manfaat motivasi yang utama adalah menciptakan gairah kerja, sehingga produktivitas kerja meningkat. Sementara itu, manfaat yang diperoleh karena bekerja dengan orang-orang yang termotivasi adalah pekerjaan dapat diselesaikan dengan tepat. Artinya pekerjaan diselesaikan sesuai standar yang benar dan dalam skala waktu yang sudah ditentukan, serta orang senang melakukan pekerjaannya. Sesuatu yang dikerjakan karena ada motivasi yang mendorongnya akan membuat orang senang mengerjakannya. Orang pun akan merasa dihargai atau diakui, hal ini karena pekerjaannya itu betul-betul berharga bagi orang yang termotivasi, sehingga orang tersebut akan bekerja keras. Hal ini dimaklumi karena dorongan yang begitu tinggi menghasilkan sesuai target yang mereka tetapkan. Kinerjanya akan dipantau oleh individu yang bersangkutan dan tidak akan membutuhkan terlalu banyak pengawasan serta semangat juangnya akan tinggi ( Ishak dan Hendri, 2003).

\section{Indikator Motivasi Kerja}

Menurut Maslow yang dikutip oleh Hasibuan (2008) bahwa motivasi kerja pegawai dipengaruhi oleh kebutuhan fisik, kebutuhan akan keamanan dan keselamatan, kebutuhan sosial, kebutuhan akan penghargaan, dan kebutuhan akan perwujudan diri. Kemudian dari faktor tersebut diturunkanlah indikator-indikator untuk megetahui tingkat motivasi pada karyawan, yaitu:

a. Kebutuhan fisik, Kebutuhan fisik ditunjukan dengan pemberian gaji yang layak kepada pegawai, pemberian bonus, uang makan, transport, fasilitas perumahan dan lain sebagainya.

b. Kebutuhan rasa aman dan keselamatan, Ditunjukan dengan fasilitas keamanan dan keselamatan kerja yang diataranya seperti adanya jaminan sosial tenaga kerja, pensiun, tunjangan kesehatan, asuransi kecelakaan, dan perlengkapan keselamatan lainnya.

c. Kebutuhan sosial, Melakukan interaksi dengan orang lain yang diantaranya menjalin hubungan kerja yang harmonis, kebutuhan untuk diterima dalam kelompok dan kebutuhan untuk mencintai dan dicintai.

d. Kebutuhan akan penghargaan, Pengakuan dan penghargaan berdasarkan kemampuannya, yaitu kebutuhan untuk dihormati dan dihargai pegawai lain dan pimpinan terhadap prestasi kerjanya.

e. Kebutuhan perwujudan diri, Sifat pekerjaan yang menarik dan menantang, dimana karyawan tersebut akan mengerahkan kecakapan, kemampuan keterampilan dan potensi lainnya. Dalam pemenuhan kebutuhan ini dapat dilakukan oleh perusahaan dengan menyelenggarakan pendidikan dan pelatihan.

\section{Kinerja}

Menurut Handoko (2001) kinerja merupakan suatu tindakan yang dilakukan karyawan dalam melaksanakan pekerjaan yang diberikan perusahaan. Menurut Hasibuan (2001) kinerja sebagai prestasi kerja, yang merupakan suatu hasil kerja yang dicapai seseorang dalam melaksanakan tugas-tugas yang dibebankan kepadanya yang didasarkan atas kecakapan, pengalaman dan kesungguhan serta waktu. Menurut Mangkunegara (2009) kinerja adalah hasil kerja baik secara kualitas dan kuantitas yang dicapai seseorang atau karyawan melalui serangkaian tindakan dan kemampuan untuk melaksanakan tugas-tugas pekerjaannya sesuai dengan tanggung jawab yang diberikan kepada karyawan oleh suatu perusahaan. Kinerja menurut Mathis dan Jackson (2006) adalah apa yang dilakukan atau tidak dilakukan oleh karyawan. Dari beberapa pendapat para ahli dapat disimpulkan bahwa kinerja karyawan adalah hasil kerja yang dilakukan oleh seseorang dalam suatu organisasi agar tercapai tujuan yang diinginkan suatu organisasi dan meminimalisir kerugian.

\section{Faktor yang Memengaruhi Kinerja Karyawan}

Menurut Mangkunegara (2009) menyatakan bahwa kinerja karyawan dipengaruhi oleh beberapa faktor diantaranya:

a. Faktor Kemampuan Secara Psikologis

Merupakan kemampuan karyawan yang terdiri dari kemampuan potensi (IQ) dan kemampuan realita (Pendidikan). Oleh karena itu karyawan perlu ditempatkan pada pekerjaan yang sesuai dengan keahliannya.

b. Faktor Motivasi

Merupakan kondisi yang menggerakkan diri karyawan terarah untuk mencapai tujuan kerja, faktor motivasi terbentuk dari sikap (Attitude) seseorang karyawan dalam menghadapi situasi (Situation) kerja. 


\section{Indikator Kinerja Pegawai}

Dalam Peraturan Pemerintah (PP) Nomor 30 Tahun 2019 tentang Penilaian Kinerja Pegawai Negeri Sipil (PNS), penilaian kinerja PNS bertujuan untuk menjamin objektivitas pembinaan PNS yang didasarkan pada sistem prestasi dan sistem karier. Penilaian dilakukan berdasarkan perencanaan kinerja pada tingkat individu dan tingkat unit organisasi, dengan memperhatikan target, capaian, hasil dan manfaat yang dicapai, serta perilaku PNS. Berikut adalah Indikator kinerja pegawai menurut Mathis dan Jackson (2006) adalah sebagai berikut:

a. Kuantitas, Kuantitas merupakan jumlah yang dihasilkan dinyatakan dalam istilah seperti jumlah unit, jumlah siklus aktivitas yang diselesaikan. Kuantitas yang diukur dari persepsi pegawai terhadap jumlah aktivitas yang ditugaskan beserta hasilnya.

b. Kualitas, Kualitas adalah ketaatan dalam prosedur, disiplin, dedikasi. Tingkat dimana hasil aktivitas yang dikehendaki mendekati sempurna dalam arti menyesuaikan beberapa cara ideal dari penampilan aktivitas. Kualitas kerja diukur dari persepsi pegawai terhadap kualitas pekerjaan yang dihasilkan serta kesempurnaan tugas terhadap keterampilan dan kemampuan pegawai.

c. Keandalan, Keandalan adalah kemampuan untuk melakukan pekerjaan yang disyaratkan dengan supervisi minimum. Menurut Zeithaml \& Berry dalam Journal of Marketing (dalam Sudarmanto, 2009:14) kehandalan yakni mencakup konsistensi kinerja dan kehandalan dalam pelayanan; akurat, benar dan tepat.

d. Kehadiran, Kehadiran adalah keyakinan akan masuk kerja setiap hari dan sesuai dengan jam kerja.

e. Kemampuan bekerja sama, Kemampuan bekerja sama adalah kemampuan seorang tenaga kerja untuk bekerja bersama dengan orang lain dalam menyelesaikan suatu tugas dan pekerjaan yang telah ditetapkan sehingga mencapai daya guna dan hasil guna yang sebesar-besarnya.

\section{Hipotesis}

Berdasarkan uraian diatas, dapat dirumuskan hipotesis penelitian sebagai berikut :

$\mathrm{H}_{1}$ : Diduga stres kerja dan motivasi kerja secara parsial berpengaruh terhadap kinerja pegawai pada BPSDM Provinsi Papua.

$\mathrm{H}_{2}$ : Diduga stres kerja dan motivasi kerja secara simultan berpengaruh terhadap kinerja pegawai pada BPSDM Provinsi Papua.

$\mathrm{H}_{3}$ : Diduga motivasi berpengaruh dominan terhadap kinerja pegawai pada BPSDM Provinsi Papua.

\section{METODE PENELITIAN}

\section{A. Definisi Operasional}

\section{Stress Kerja}

Stres kerja merupakan suatu kondisi dimana ketegangan jiwa yang muncul diakibatkan oleh interaksi manusia dengan berbagai hal-hal maupun faktor-faktor yang ada dalam lingkup pekerjaannya yang menyebabkan terjadi perubahan yang mengakibatkan penyimpangan.

\section{Motivasi Kerja}

Motivasi adalah salah satu faktor yang menyebabkan seseorang melakukan suatu tindakan dengan cara-cara tertentu sesuai dengan kebutuhannya

\section{Kinerja}

Kinerja yaitu suatu pencapaian ataupun hasil kerja yang diperoleh dari seseorang dalam melaksanakan tugas dan tanggung jawabanya sesuai dengan kriteria yang telah ditetapkan oleh suatu organisasi dengan waktu yang telah ditetapkan

\section{B. Populasi, Sampel dan Teknik Pengambilan Sampel}

\section{Populasi}

Populasi adalah semua unit analisis yang diteliti dalam suatu penelitian, baik lembaga atau instansi maupun wujud manusia. Menurut Arikunto (2006) populasi merupakan seluruh elemen yang berada pada wilayah penelitian. Adapun populasi yang digunakan dalam penelitian ini adalah seluruh pegawai Badan Pengembangan Sumber Daya Manusia yang berjumlah 80 pegawai. 


\section{Sampel}

Sampel adalah sebagian atau wakil dari populasi yang diteliti (Arikunto, 2006) berdasarkan pendapat tersebut maka sampel dalam penelitian ini yaitu berjumlah 45 pegawai.

\section{Teknik Pengambilan Sampel}

Teknik pengambilan sampel yang digunakan adalah Total sampling atau Sampel jenuh dengan seluruh populasi dijadikan sampel. Setelah kuesioner disebarkan sebanyak 80 kuesioner, 45 kuesioner yang dikembalikan selama waktu yang telah ditetapkan. Jadi sampel yang digunakan dalam penelitian ini sebanyak 45 responden.

\section{Jenis Dan Sumber Data}

\section{Jenia Data}

Adapun jenis data yang diperlakukan dalam penelitian ini adalah:

a. Data kuantitatif Menurut Sugiyono (2015) data kuantitatif adalah data yang berbentuk angka, atau data kuantitatif yang diangkakan (scoring).

b. Data kualitatif Menurut Sugiyono (2015) data kualitatif adalah data yang berbentuk kalimat, kata atau gambar.

\section{Sumber Data}

Sumber data yang digunakan dalam penelitian ini adalah:

a. Data primer Adapun jenis data yang digunakan adalah berupa kuesioner mengenai stres kerja dan motivasi kerja, serta kinerja pegawai.

b. Data sekunder

Biasanya diperoleh dari perpustakaan atau dari laporan-laporan penelitian terdahulu, gambaran umum objek, buku, terkait dengan penulisan teori dan refrensi jurnal.

\section{Metode Analisis Data}

Guna untuk memperoleh data yang diinginkan sesuai dengan gejala yang dihadapi, maka penulis melakukan pengukuran dengan menggunakan skala Likert, yaitu metode yang digunakan untuk mengukur sikap, pendapat dan persepsi seseorang atau sekelompok orang tentang suatu fenomena sosial (Sugiyono, 2012). Skala likert yang digunakan untuk menjawab pernyataan penelitian memiliki empat kategori, yaitu sebagai berikut :
a. Sangat Setuju (SS) $\quad=5$
b. Setuju $(S) \quad=4$
c. Netral (N) $\quad=3$
d. Tidak Setuju (TS) $\quad=2$
e. Sangat Tidak Setuju (STS) $=1$

\section{E. Uji Validitas dan Uji Reabilitas}

\section{Uji Validitas}

Uji validitas digunakan untuk mengukur sah atau tidaknya suatu kuesioner. Suatu kuesioner dikatakan valid jika pertanyaan dalam kuesioner mampu untuk mengungkapkan sesuatu yang akan diukur oleh kuesioner tersebut. Pengujian validitas ini menggunakan Pearson Correlation yaitu dengan cara menghitung korelasi antara nilai yang diperoleh dari pertanyaan-pertanyaan. Suatu pertanyaan dikatakan valid jika tingkat signifikan berada di bawah 0,05. (Ghozali, 2012).

\section{Uji Reabilitas}

Uji reliabilitas sebenarnya adalah alat untuk mengukur suatu kuesioner yang merupakan indikator dari variabel atau konstruk. Suatu kuesioner dikatakan reliabel atau handal jika jawaban seseorang terhadap pertanyaan adalah 
konsisten atau stabil dari waktu ke waktu. Butir kuesioner dikatakan reliabel (layak) jika cronbach"s alpha > 0,06

F. Uji Asumsi Klasik

dan dikatakan tidak reliabel jika cronbach"s alpha <0,06 (Ghozali, 2012).

Penelitian ini melakukan uji asumsi klasik yang terdiri dari uji normalitas, Uji Multikoliniearitas, Uji Heteroskedastisitas, dan Uji Autokorelasi sebelum melakukan analisis regresi berganda.

\section{G. Analisis Regresi Berganda}

Menurut Sugiyono (2016) analisis regresi linier berganda merupakan regresi yang memiliki satu variabel dependen dan dua atau lebih variabel independen. Adapun persamaan regresi berganda dapat dirumuskan sebagai berikut:

$$
\mathrm{Y}=\alpha+\mathrm{b} 1 \mathrm{X} 1+\mathrm{b} 2 \mathrm{X} 2+\mathrm{e}
$$

Keterangan:

a : Konstanta

b1 : Koefisien Regresi Stres Kerja

b2 : Koefisien Regresi Motivasi Kerja

$Y \quad$ : Variabel Dependent (Kinerja Pegawai)

X1 : Variabel Independent (Stres Kerja)

X2 : Variabel Independent (Motivasi Kerja)

e : Standar eror

\section{HASIL DAN PEMBAHASAN}

\section{A. Karakteristik Responden}

1. Karakteristik responden berdasarkan jenis kelamin

Tabel 1. Data responden berdasarkan Jenis Kelamin

\begin{tabular}{|c|c|c|c|}
\hline No. & Jenis Kelamin Responden & Jumlah & Presentase \\
\hline 1. & Laki - Laki & 26 & $57,77 \%$ \\
\hline 2. & Perempuan & 19 & $42,22 \%$ \\
\hline & Jumlah Responden & 45 & $100 \%$ \\
\hline
\end{tabular}

Sumber: data diolah, 2020

Dari tabel 4.1 diatas diperoleh hasil bahwa pegawai Badan Pengembangan Sumber Daya Manusia Provinsi Papua berjumlah 45 orang, terdiri dari 26 orang pegawai laki-laki atau sebesar $57,77 \%$ dari total populasi dan sebanyak 19 orang pegawai perempuan atau sebesar $42,22 \%$ dari total pegawai pada kantor.

\section{Karakteristik responden berdasarkan usia}

Tabel 2. Data responden berdasarkan usia

\begin{tabular}{|c|c|c|}
\hline Usia & Jumlah & Presentase \\
\hline 21-30 Tahun & 2 & $4.44 \%$ \\
\hline 31-40 Tahun & 8 & $17,77 \%$ \\
\hline 41-50 Tahun & 20 & $44,44 \%$ \\
\hline 51- Pensiun & 15 & $33,33 \%$ \\
\hline Jumlah & $\mathbf{4 5}$ & $\mathbf{1 0 0 \%}$ \\
\hline
\end{tabular}

Data tabel usia responden pada tabel 4.2 di atas diperoleh hasil bahwa usia pegawai BPSDM Provinsi Papua terdiri dari 2 orang pegawai berumur 21-30 tahun atau sebesar $4.44 \%$ dari total pegawai, kemudian sebanyak 8 orang pegawai berumur $31-40$ tahun atau $17,77 \%$ dari total pegawai pada kantor, untuk karyawan yang berumur $41-50$ tahun atau sebesar $44,44 \%$ berjumlah 20 orang pegawai dari total pegawai kantor, sedangkan untuk umur 51 pensiun berjumlah 15 orang dengan jumlah presentase sebesar $33,33 \%$ dari total populasi. 
3. Karakteristik responden berdasarkan pendidikan terakhir

Tabel 3. Data Responden Berdasarkan Pendidikan Terakhir

\begin{tabular}{|c|c|c|}
\hline Pendidikan Terakhir & Jumlah & Presentase \\
\hline SMA & 8 & $17,77 \%$ \\
\hline D3 & 3 & $6,66 \%$ \\
\hline S1 & 15 & $33,33 \%$ \\
\hline S2 3 & 17 & $37,77 \%$ \\
\hline Jumlah & 2 & $4,44 \%$ \\
\hline
\end{tabular}

Dari tabel 4.3 dapat dilihat bahwa responden yang memiliki tingkat pendidikan terakhir SMA ada sebanyak 8 orang atau sebanyak 17,77\%. Responden dengan pendidikan terakhir D3 sebesar 6,66\% atau berjumlah 3 orang. Responden dengan pendidikan terakhir S1 sebesar 15 orang dengan presentase 33,33\%. Responden dengan pendidikan terakhir S2 sebesar 17 orang dengan presentase 37,77\%. Responden dengan pendidikan terakhir S3 sebesar 2 orang dengan presentase $4,44 \%$.

\section{Karakteristik responden berdasarkan lama kerjanya}

Tabel 4. Data responden berdasarkan lama kerjanya

\begin{tabular}{|c|c|c|}
\hline Lama Bekerja & Jumlah & Presentase \\
\hline Dibawah 10 tahun & 6 & 13,33 \\
\hline $11-20$ tahun & 18 & $40 \%$ \\
\hline $21-30$ tahun & 19 & $42,22 \%$ \\
\hline Diatas 30 tahun & 2 & $4.4 \%$ \\
\hline Jumlah & $\mathbf{4 5}$ & $\mathbf{1 0 0 \%}$ \\
\hline
\end{tabular}

Berdasarkan tabel 4.4 menunjukkan 13,33\% atau 6 responden telah bekerja dibawah 10 tahun. Sedangkan $40 \%$ atau 18 responden bekerja selama 11-20 tahun dan yang bekerja $21-30$ tahun sebesar $42,22 \%$ atau berjumlah 19 orang sedangkan yang bekerja di atas 30 tahun hanya sebesar $4,4 \%$ atau 2 orang dari total pegawai kantor.

\section{B. Uji Validitas dan Reabilitas \\ 1. Uji Validitas}

Uji validitas dilakukan untuk mengukur data yang didapat daru masing-masing variabel setelah penelitian dan merupakan data yang valid dengan alat ukur yang digunakan (kuesioner). Adapun ketentuan yang digunakan untuk mengukur uji validitas adalah:

a. Jika $r$ hitung $>r$ tabel, maka butir pertanyaan tersebut valid

b. Jika $r$ hitung $<\mathrm{r}$ tabel, maka butir pertanyaan tersebut tidak valid

Penyebaran kuesioner diberikan kepada 45 orang responden, dengan nilai $r$ tabel berdasarkan ketentuan $\mathrm{df}=$ jumlah responden $=45$ orang dengan tingkat signifikan sebesar $5 \%$, angka yang diperoleh sebesar $=0,287$. Peneliti memperoleh hasil bahwa seluruh pertanyaan valid, karena nilai korelasi berada di atas 0,287 dan signifikansi < 0,05 , dengan demikian seluruh pertanyaan dapat dipergunakan dalam penelitian.

\section{Uji Reabilitas}

Untuk uji reliabilitas, semua item yang valid dimasukkan sedangkan yang tidak valid, tidak dimasukkan dalam uji reliabilitas. Karena dalam uji validitas di atas semua item valid, maka dimasukkan ke dalam uji reliabilitas. Untuk menentukan suatu instrumen reliabel atau tidak, maka bisa menggunakan batas nilai Alpha 0,6. Reliabilitas kurang dari 0,6 adalah kurang baik, sedangkan 0,7 dapat diterima dan di atas 0,8 adalah baik. Nilai Cronbach Alpha untuk variabel stress kerja, motivasi kerja dan motivasi pegawai lebih dari 0,6, maka dapat disimpulkan bahwa instrumen penelitian telah reliabel. 


\section{Uji Asumsi Klasik}

Sebelum melakukan pengujian dengan menggunakan analisis regresi linier berganda. Peneliti melakukan uji asumsi klasik dan memperoleh hasil penelitian ini dapat menggunakan analisis regresi linier berganda.

\section{Analisis Regresi Linier Berganda}

Tabel 5. Hasil Analisis Regresi linier Berganda

\begin{tabular}{|c|c|c|c|c|c|}
\hline \multirow[b]{2}{*}{ Model } & \multicolumn{2}{|c|}{ Unstandardized Coefficients } & \multirow{2}{*}{$\begin{array}{c}\begin{array}{c}\text { Standardized } \\
\text { Coefficients }\end{array} \\
\text { Beta }\end{array}$} & \multirow[b]{2}{*}{ t } & \multirow[b]{2}{*}{ Sig. } \\
\hline & B & Std. Error & & & \\
\hline 1 (Constant) & 11.138 & 3.104 & & 3.589 & .001 \\
\hline Stres Kerja & .368 & .157 & .333 & 2.347 & .024 \\
\hline Motivasi Kerja & .305 & .103 & .422 & 2.974 & .005 \\
\hline
\end{tabular}

a. Dependent Variable: Kinerja Pegawai

Berdasarkan tabel 5 di atas, menghasilkan persamaan regresi linear berganda sebagai berikut:

$$
Y=11,138+0,368 \times 1+0,305 X 2+e
$$

Hasil analisis tersebut dapat diinterpretasikan sebagai berikut:

1. Nilai konstanta persamaan di atas sebesar 11,138 angka tersebut menunjukkan bahwa, jika $X_{1}$ (stres kerja) dan $\mathrm{X}_{2}$ (motivasi kerja) konstan atau $\mathrm{X}=0$ maka, kinerja pegawai sebesar 11,138.

2. $X_{1}$ (stres kerja) menunjukkan nilai koefisien sebesar 0,368 , hal ini berarti bahwa jika terjadi peningkatan $1 \%$ terhadap stres kerja pada Badan Pengembangan Sumber Daya Manusia Provinsi Papua, maka kinerja pegawai akan meningkat sebesar 0,368 dengan asumsi variabel independen yang lain dianggap konstan.

3. $\mathrm{X}_{2}$ (motivasi kerja) menunjukkan nilai koefisien sebesar 0,305 , hal ini berarti bahwa jika terjadi peningkatan 1\% terhadap motivasi kerja pada Badan Pengembangan Sumber Daya Manusia Provinsi Papua, maka kinerja pegawai akan meningkat sebesar 0,305 dengan asumsi variabel independen yang lain dianggap konstan.

\section{E. Pengujian Hipotesis}

1. Ujit

Tabel 5. Hasil Uji-t

\begin{tabular}{|c|c|c|c|c|c|}
\hline \multirow[b]{2}{*}{ Model } & \multicolumn{2}{|c|}{ Unstandardized Coefficients } & \multirow{2}{*}{$\begin{array}{c}\begin{array}{c}\text { Standardized } \\
\text { Coefficients }\end{array} \\
\text { Beta }\end{array}$} & \multirow[b]{2}{*}{$t$} & \multirow[b]{2}{*}{ Sig. } \\
\hline & B & Std. Error & & & \\
\hline $1 \quad$ (Constant) & 11.138 & 3.104 & & 3.589 & .001 \\
\hline Stres Kerja & .368 & .157 & .333 & 2.347 & .024 \\
\hline Motivasi Kerja & .305 & .103 & .422 & 2.974 & .005 \\
\hline
\end{tabular}

a. Dependent Variable: Kinerja Pegawai

Sumber : data diolah, 2020

Berdasarkan tabel di atas dapat dijelaskan bahwa statistik uji t terhadap stres kerja (X1) sebesar 2,347 dengan tingkat signifikansi sebesar 0,024 . Nilai statistik uji t hitung tersebut lebih besar daripada tabel $(2,347>$ 1,680 ) dengan signifikan lebih kecil daripada $a=0,05$. Pengujian ini menunjukkan bahwa Ha diterima sehingga dapat disimpulkan bahwa stres kerja berpengaruh terhadap kinerja pegawai pada Badan Pengembangan Sumber 
Daya Manusia Provinsi Papua. Pada variabel motivasi kerja (X2) didapatkan statistik uji t sebesar 2,974 dengan tingkat signifikansi sebesar 0,005. Nilai statistik uji thitung tersebut lebih besar daripada $t_{\text {tabel }}(2,974>1,680)$ dan juga signifikan lebih kecil daripada $\alpha=0,05$. Pengujian ini menunjukkan bahwa Ha diterima sehingga dapat disimpulkan bahwa motivasi kerja berpengaruh terhadap kinerja pegawai pada Badan Pengembangan Sumber Daya Manusia Provinsi Papua. Pengujian hipotesis membuktikan bahwa, stres kerja mampu memberikan dampak positif terhadap kinerja pegawai pada Badan Pengembangan Sumber Daya Manusia Provinsi Papua. Hal ini dibuktikan dengan besarnya nilai uji t terhadap stres kerja (X1) dengan tingkat signifikan. Nilai uji thitung tersebut lebih besar dari $t_{\text {tabel. }}$ Pada Penguji penelitian ini sejalan dengan penelitian Noviansyah dan Zunaidah (2011). hasil dari penelitian tersebut menunjukkan bahwa stres kerja mampu memberikan dampak positif terhadap kinerja pegawai.Menurut

Mangkunegara (2008) Stres kerja adalah perasaan tertekan yang dialami pegawai dalam menghadapi pekerjaan. Pada prakteknya jika stres yang dialami oleh pegawai tidak segera teratasi maka akan berdampak buruk terhadap pegawai tersebut. Pegawai yang berada dalam kondisi stres akan memicu terjadinya burn out yang merupakan kondisi awal kemunculan kelelahan emosional. Menurut (Suprihanto, 2003) penyebab stres kerja yaitu penyebab fisik, beban kerja, sifat pekerjaan, dan kesulitan-kesulitan yang terjadi diluar kantor. Menurut Asmike dan Setiono (2020) Stres dapat dinyatakan positif dan merupakan suatu peluang apabila stres tersebut dapat mempengaruhi mereka untuk meningkatkan usahanya agar memperoleh hasil optimal. Stres dapat dikatakan negatif apabila stres tersebut menyebabkan hasil yang menurun pada produktifitas pegawai.

Berdasarkan hasil penelitian dapat diketahui bahwa motivasi kerja terbukti berpengaruh postif dan signifikan terhadap kinerja pegawai. Hasil frekuensi mengenai variabel motivasi kerja pada Badan Pengembangan Sumber Daya Manusia Provinsi Papua tergolong baik karena rata-rata jawaban responden dari 6 item pertanyaan yang diberikan memiliki jawaban dalam kategori setuju. Hal ini dibuktikan dengan besarnya nilai uji t terhadap motivasi kerja (X2) dengan tingkat signifikan. Nilai uji thitung tersebut lebih besar dari tabel. Dengan demikian dapat disimpulkan bahwa motivasi kerja diberikan oleh pimpinan/organsiasi kepada pegawai mampu meningkatkan kinerja pegawai pada Badan Pengembangan Sumber Daya Manusia Provinsi Papua. Penelitian ini sesuai dengan penelitian Dewi dan Wibawa (2016) hasil dari penelitian tersebut menunjukkan bahwa motivasi kerja secara individu mampu memberikan dampak positif terhadap kinerja karyawan. Hasil analisis membuktikan bahwa, stres kerja mampu memberikan dampak positif terhadap kinerja pegawai pada Badan Pengembangan Sumber Daya Manusia Provinsi Papua.

Motivasi dapat diartikan sebagai dorongan yang mengakibatkan seorang anggota organisasi mau dan rela waktunya untuk menyelenggarakan berbagai kegiatan yang menjadi tanggung jawabnya dan menunaikan kewajibannya dalam rangka pencapaian tujuan dan berbagai sasaran organisasi yang ditentukan sebelumnya (Siagian, 2003). Untuk dapat memberikan hasil kerja yang berkualitas dan berkuantitas maka seorang pegawai membutuhkan motivasi kerja dalam dirinya yang akan berpengaruh terhadap semangat kerjanya sehingga meningkatkan kinerjanya. Telah lama diketahui bahwa manusia adalah makhluk sosial. Sebagai makhluk sosial ia membutuhkan rasa sayang, pengakuan keberadaan, rasa ingin memiliki berbagai kebutuhan tersebut, manusia bekerja dan berusaha dengan sekuat tenaga untuk memenuhi keinginan itu.

\section{Uji F}

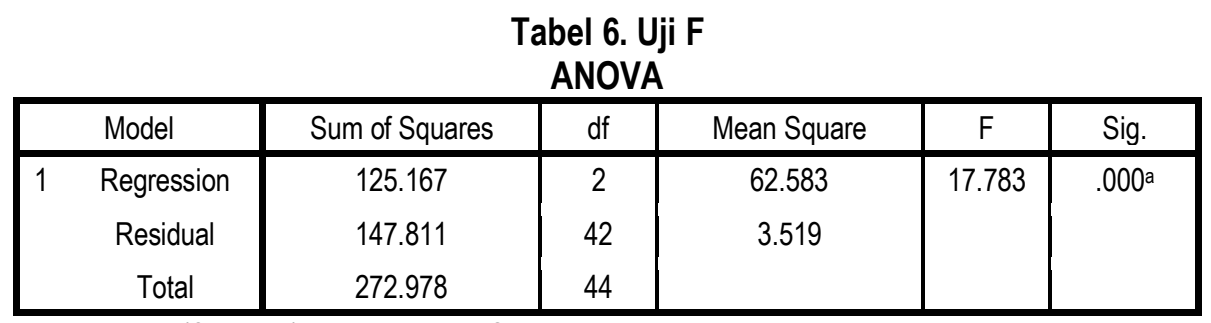

a. Predictors: (Constant), Motivasi Kerja, Stres Kerja

b. Dependent Variable: Kinerja Pegawai

Sumber : data diolah, 2020 
Pengujian pengaruh variabel bebas secara bersama-sama terhadap variabel terikatnya dilakukan dengan menggunakan uji $F$. Hasil perhitungan statistik menunjukkan nilai $F$ hitung $=17,783$ dengan signifikansi sebesar $0,000<0,05$. Dengan nilai signifikansi di bawah 0,05 menunjukkan bahwa secara bersama-sama stres kerja dan motivasi kerja berpengaruh yang positif dan signifikan terhadap kinerja pegawai pada Badan Pengembangan Sumber Daya Manusia Provinsi Papua.

Hasil penelitian menunjukkan bahwa secara bersama-sama, variabel stres kerja dan motivasi kerja mampu memberikan dampak positif terhadap kinerja pegawai pada Badan Pengembangan Sumber Daya Manusia Provinsi Papua. Kedua variabel secara bersama-sama memberikan kontribusi sebesar $(0,433)$ atau sama dengan $43,3 \%$ terhadap kinerja pegawai. Hal ini dapat dijelaskan bahwa semakin rendah stres kerja yang dialami oleh pegawai dan didukung oleh motivasi kerja dari pimpinan, akan meningkatkan kinerja pegawai sebesar $43,3 \%$. Menurut Sedarmayanti (2009) Stres sering diartikan sebagai kelebihan tuntutan atas kemampuan individu dalam memenuhi kebetuhan. Masalah yang terdapat dalam lingkungan keluarga, kegiatan sosial, pekerjaan di kantor, kegiatan di waktu senggang, maupun yang ada hubungannya dengan orang lain, dapat menimbulkan beban yang berlebihan. Menurut Hasibuan (2003) bahwa motivasi kerja adalah pemberian daya penggerak yang menciptakan kegairahan kerja seseorang agar mereka mau bekerja sama, bekerja efektif dan terintegrasi dengan segala daya upayanya untuk mencapai kepuasan. Faktor pendorong penting yang menyebabkan manusia bekerja adalah adanya kebutuhan yang harus dipenuhi. Penelitian ini sejalan dengan penelitian Noviansyah dan Zunaidah (2011) hasil dari penelitian tersebut menunjukkan secara bersama-sama stres kerja dan motivasi kerja mampu memberikan dampak positif terhadap kinerja karyawan.

\section{Variabel yang domonan terhadap Kinerja Pegawai}

Berdasarkan hasil pembahasan secara individu dapat diketahui bahwa motivasi kerja mampu memberikan dampak secara dominan pada Badan Pengembangan Sumber Daya Manusia Provinsi Papua dengan kontribusi nilai partial sebesar $41,7 \%$. Hasil ini sejalan dengan penelitian Dewi dan Wibawa (2016) hasil dari penelitian tersebut menunjukkan bahwa motivasi memberikan dampak dominan terhadap kinerja karyawan. Motivasi dapat diartikan sebagai faktor pendorong yang berasal dalam diri manusia, yang akan mempengaruhi cara bertindak seseorang. Menurut Hasibuan (2003) bahwa motivasi kerja adalah pemberian daya penggerak yang menciptakan kegairahan kerja seseorang agar mereka mau bekerja sama, bekerja efektif dan terintegrasi dengan segala daya upayanya untuk mencapai kepuasan kerja. Kepuasaan kerja harus ditingkatkan lebih baik untuk mengimbangi kondisi dari lingkungan yang selalu membutuhkan tugas kerja yang cakap dan siap dalam menghadapi berbagai tantangan dan masalah-masalah yang timbul dalam menjalankan tugasnya sehingga mampu memegang tanggung jawabnya masing-masing. Faktor pendorong penting yang menyebabkan manusia bekerja adalah adanya kebutuhan yang harus dipenuhi. Kebutuhan ini dapat berupa kebutuhan ekonomis yaitu kebutuhan untuk mendapatkan uang, sedangkan kebutuhan non ekonomis merupakan kebutuhan untuk memperoleh kedudukan dan keinginan untuk berubah menjadi lebih baik. Dengan segala kebutuhan tersebut, seseorang dituntut untuk lebih giat dan aktif dalam bekerja. Dapat disimpulkan bahwa, keberadaan motivasi penting karena dengan motivasi ini diharapkan setiap individu karyawan mau bekerja keras dan antusias untuk mencapai produktivitas kerja yang tinggi (Hasibuan, 2008).

\section{PENUTUP}

\section{A. Simpulan}

Berdasarkan hasil penelitian yang telah dilakukan dan pembahasan yang telah dikemukakan sebelumnya, maka dapat disimpulkan hal-hal sebagai berikut:

1. Secara individu stres kerja dan motivasi kerja mampu memberikan dampak positif terhadap kinerja pegawai pada Badan Pengembangan Sumber Daya Manusia Provinsi Papua, hal ini berarti bahwa semakin rendah tingkat stres pegawai pada organisasi dan semakin baik motivasi kerja yang diberikan oleh pimpinan kepada bawahan, akan meningkatkan variabel kinerja pegawai, sebaliknya semakin tinggi tingkat stres karyawan dan semakin rendah motivasi yang diberikan oleh pimpinan/organisasi kepada pegawai, maka kinerja pegawai juga akan menurun. 
2. Secara bersama-sama stres kerja dan motivasi kerja mampu memberikan dampak positif terhadap kinerja pegawai pada Badan Pengembangan Sumber Daya Manusia Provinsi Papua. Hal ini berarti bahwa, stres kerja dan motivasi kerja dalam waktu yang sama mampu meningkatkan kinerja pegawai pada Badan Pengembangan Sumber Daya Manusia Provinsi Papua.

3. Variabel motivasi kerja memiliki dampak yang dominan terhadap kinerja pegawai pada Badan Pengembangan Sumber Daya Manusia Provinsi Papua. Hal ini berarti bahwa, motivasi kerja memiliki dampak yang paling erat dalam meningkatkan kinerja pegawai pada Badan Pengembangan Sumber Daya Manusia Provinsi Papua.

\section{B. Saran}

Saran yang dapat diambil dari penelitian ini adalah sebagai berikut :

1. Untuk mengatasi tingkat stres kerja pegawai pada Badan Pengembangan Sumber Daya Manusia Provinsi Papua perlu mengatur jumlah pegawai yang ditetapkan dalam setiap bagian pekerjaannya supaya tidak terjadi perdebatan diantara sesama pegawai dalam pembagian kerja, instansi juga harus menyiapkan alat yang lebih modern dan mengadakan alat yang belum ada untuk mempercepat dan mempermudah pegawai dalam bekerja, serta memberikan pelatihan kepada pegawai tentang cara menggunakan alat-alat dengan baik.

2. Badan Pengembangan Sumber Daya Manusia Provinsi Papua perlu memperhatikan faktor motivasi dengan memberikan dorongan seperti menaikkan gaji yang sesuai agar memicu kinerja pegawai sehingga tujuan instansi dapat tercapai.

3. Hasil penelitian menunjukkan adanya dampak stres kerja dan motivasi kerja terhadap kinerja pegawai yang rendah, sedangkan kinerja tinggi bisa dipengaruhi oleh faktor-faktor lain seperti kepuasan kerja, kondisi fisik pekerjaan, sistem kompensasi, desain pekerjaan, dan aspek-aspek ekonomis, serta perilaku lainnya. Peneliti selanjutnya diharapkan untuk dapat mengembangkan penelitian ini dengan menambahkan variabel-variabel yang tidak penulis teliti.

\section{DAFTAR PUSTAKA}

Arikunto, Suharsimi. 2006. Prosedur Penelitian Suatu Pendekatan Praktek. Jakarta: PT. Rineka Cipta.

Asmike, Metit dan Bagus Setiono, 2020. Pengaruh Person Job-Fit Dan Stres Kerja Terhadap Kepuasan Kerja Karyawan (Studi pada Karyawan Outsource Bank BCA KCU Madiun). Vol.3, No.2:179)

Dewi, Ari Sintya dan Artha Wibawa. 2016. Pengaruh Stres Kerja Dan Motivasi Kerja Terhadap Kinerja Karyawan PT. Bank BPD Bali Cabang Ubud. Vol. 5,No.12:7583-7606.

Dwiyanti. 2001. Stres Kerja di Lingkungan DPRD: Study tentang Anggota DPRD di kota Surabaya, Malang dan Kabupaten Jember. Jurnal Masyarakat, Kebudayaan dan Politik. Surabaya: Fakultas Kesehatan Masyarakat Universitas Airlangga.

Ghozali, Imam. 2012. Aplikasi Analisis Multivariate Dengan Program IBM SPSS 20. Semarang: Badan Penerbit Universitas Diponegoro

Gibson, James L. 1994. Organisasi dan Manajemen : Perilaku, Struktur. Jakarta: Penerbit Erlangga.

Grifin R. W. 2003. Manajemen. Jakarta: Erlangga.

Hasibuan, M. 2001. Manajemen Sumber Daya Manusia. Jakarta: PT. Bumi Aksara.

Hasibuan, M. 2003. Organisasi dan Motivasi. Dasar peningkatan Produktivitas. Jakarta: PT. Bumi Aksara.

Hasibuan, M. 2008. Manajemen Dasar, Pengertian, Dan Masalah. Jakarta: PT. Bumi Aksara.

Hasibuan, M. 2013. Manajemen Sumber Daya Manusia:Pengertian Dasar, Pengertian, dan Masalah. Jakarta: PT. Toko Gunung Agung.

Handoko, T. Hani. 2001. Manajemen Personalia dan Sumber Daya Manusia. Edisi 2. Yogyakarta: BPFE.

Ishak, Arep dan Tanjung Hendri. 2003.Manajemen Motivasi. Jakarta: Gramedia Widiasarana. 
Luthans, Fred. 2005. Perilaku Organisasi. Edisi sepuluh. Yogyakarta: Penerbit Erlangga.

Mangkunegara, A.A. Anwar Prabu. 2008. Manajemen Sumber Daya Manusia. Cetakan kelima, Penerbit : PT. Remaja Rosdakarya. Bandung.

Mangkunegara, A.A. Anwar Prabu. 2009. Manajemen Sumber Daya Manusia. Bandung: PT. Remaja Rosdakarya

Mathis, Robert L dan John,H. Jackson. 2001. Manajemen Sumber Daya Manusia. Jakarta: Buku Kedua.

Mathis, Robert L dan John, H. Jackson. 2006. Human Resource Management (Manajemen Sumber Daya Manusia). Edisi 10. Jakarta: Salemba Empat.

Mulyadi. 2012. Pengaruh Stres Terhadap Semangat Kerja Karyawan BAPPEDA Provinsi Nangroe Aceh Darussalam.

Noviansyah dan Zunaidah, 2011. Pengaruh Stres Kerja Dan Motivasi Kerja Terhadap Kinerja Karyawan PT. Perkebunan Minanga Ogan Baturaja.Vol.9, No. 18:44-58.

Suprihanto John, dkk. 2003. Perilaku Organisasional. Yogyakarta: Sekolah Tinggi llmu Ekonomi YKPN.

Robbins S. P. 2008. Perilaku Organisasi. Jakarta: Salemba Empat.

Romli. 2010. Pengaruh Stres terhadap Motivasi Kerja dan dampaknya terhadap Kinerja Karyawan PT. BPRS PNM AI Ma'some

Sedarmayanti. 2009. Sumber Daya Manusia dan Produktivitas Kerja. Bandung: Mandar Maju.

Sinaga, Timbul dan Mutiara Sinambela, 2013. Pengaruh Stres Kerja Terhadap Motivasi Dan Kinerja Auditor Pada Kantor Akuntan Publik Di Kota Medan. Vol.XVII, No.01:75-83

Siagian, Sondang P. 2003. Manajemen Sumber Daya Manusia. Jakarta: Bumi Aksara

Sugiyono. 2015. Metode Penelitian Kuantitatif, Kualitatif dan R\&D. Bandung: Alfabeta.

Sugiyono. 2016. Metode Penelitian Kuantitatif, Kualitatif dan R\&D. Bandung: Alfabeta.

Yusuf, Syamsu. 2004. Mental Hygine Pengembangan kesehatan Mental dalam kajian psikologi dan Agama. Bandung: Pustaka Banii Quraisy. 